\title{
SOME SPINY BACKED ORB-WEAVING SPIDERS (ARANEAE: ARANEIDAE) FROM BANGLADESH
}

\author{
Biswas, V. and D. Raychaudhuri ${ }^{1}$ \\ Department of Zoology, Khulna Govt. Womens' College, Khulna-9000, Bangladesh; ${ }^{1}$ Department of \\ Agricultural Biotechnology, IRDM Faculty Centre, Ramkrishna Mission Vivekananda Educational and \\ Research Institute, Narendrapur, Kolkata-700 103, India
}

\begin{abstract}
Spiny backed orb-weaving spiders sampled from different areas of Khulna and Bagerhat, Bangladesh were dealt with. Three species of the genus Gasteracantha Sundevall were recorded that includes one new species G. chowdhuryi n. sp. Generic diagnosis, illustrated description and distribution together with key to the species were provided herewith.
\end{abstract}

Key words: Spiny backed orb-weavers; Araneae; Araneidae; Gasteracantha; Bangladesh.

\section{INTRODUCTION}

Orb-weaving spiders are unique, most beautiful and fascinating group among all spiders. These are well known to all by their body appearance and peculiar geometric webs. They belong to the family Araneidae (=Argiopidae), members of which are commonly found on the webs of their own made in the agricultural fields, gardens and forests. Spiny backed orb-weavers are members of this group, a name commonly used for the genus Gasteracantha Sundevall.

Genus Gasteracantha was first erected by Sundevall in 1833 with the type-species G. concriformis (Linnaeus 1758). At present the genus contains a total of 70 species world-wide (World Spider Catalog 2019), 18 species in other Asian countries (Tikader 1982, Keswani et al. 2012, Raychaudhuri and Saha 2014, Yaginuma1986, Barrion and Litsinger 1995, Yin et al.1997, Song et al. 1999, Tanikawa 2007, Kim and Lee 2012) but in Bangladesh, only five (5) species of this genus are reported (Chowdhury and Nagari 1981, Chowdhury and Pal 1984, Okuma et al. 1993, Biswas 2009, Biswas et al. 1993, Begum and Biswas 1997).

Genus Gasteracantha, a potential predatory orb-weaving spider in the agricultural fields, gardens and forests of Bangladesh. Considering their taxonomic and ecological importance, the present study was undertaken to know the diversity and distribution of the species. The present paper contains description of only three species of which one species $G$. chowdhuryi n. sp. was described as new to science. Generic diagnosis, illustrated description and distribution together with key to the species were provided herewith.

\section{Collection}

\section{MATERIAL AND METHODS}

The study was initiated with the collection of the specimens from the webs made by them in between branches of herbs and shrubs. Collection was made directly by shaking the branches of trees on an inverted umbrella or white cloths placed underneath the webs. The collected specimens were immediately anesthetized by transferring to a large killing jar containing chloroform. Specimens thus paralyzed, were then taken to the laboratory (Department of Zoology, Kolkata University) for sorting, preservation and study. 


\section{Preservation}

In the laboratory, the specimens were then transferred to a petridish filled with $70 \%$ ethyl alcohol and kept up to 2-3 hours for relaxation of body muscles and appendages (Chowdhury and Nagari 1981). The body parts of spiders (e.g. - legs, chelicerae, pedipalps etc.) were stretched by using fine brushes, forceps, needles etc. All these were done in a alcohol-filled petridish under a Stereo binocular microscope. Specimens were then preserved in specimen vial (single specimen in single vial) temporarily in $70 \%$ alcohol for further study. After study, all the specimens were preserved permanently in Audman's preservatives (90 parts $70 \%$ alcohol +5 parts Glycerine +5 parts glacial Acetic acid). The preservation techniques were followed as recommended by Lincoln and Sheals (1985) and Tikader (1987).

\section{Identification}

Identification upto species level and detail taxonomic study was done based on various relevant taxonomic literatures of home and abroad (Levi 1965, Kolosvary 1931, Kaston 1972, Tikader 1982, 1987, Biswas 2009, Okuma et al. 1993, Yin et al. 1997, Song et al.1999, Barrion and Litsinger 1995, Yaginuma 1986, Tanikawa 2007, Davies 1988, Koh 1989, Kim and Lee 2012, Raychaudhuri and Saha 2014). The identity of the species was later confirmed from the Zoological Survey of India, Kolkata.

The types are at present in the collection of the Department of Zoology, Khulna Government Womens' College, Khulna and will be deposited to the Museum of the Department of Zoology, University of Dhaka, in due course of time. Preserved specimens of spiders were arranged in a petridish or cavity block on submerged cotton or white beach filled with $70 \%$ alcohol for study under a Stereo binocular microscope.

During study, female epigynum and male genitalia were dissected out from the body. After dissection, the epigynum was cleared in clove oil for 6-12 hours. It was then kept permanently in a microvial corked with cotton along with the mother spider in a large tube (Levi 1965) and preserved permanently in Audman's preservative following Tikader (1987). The male pedipalps after removal from the body were boiled first in 10\% $\mathrm{KOH}$ solutions for 5-10 minutes. Thus, the different parts were expanded and then placed under a Stereo binocular microscope for study. The male palps were also kept in the same way along with the male spider in Audman's preservative permanently.

\section{Drawing and Photographs}

Figures of dorsal habitus of spiders and its different body parts were drawn with the help of a Camera lucida fitted with the Stereo binocular microscope (SZX 7 Olympus). The photographs were taken both in the field and laboratory with a digital camera fitted with the microscope.

\section{RESULTS AND DISCUSSION}

\section{Taxonomy}

Family: ARANEIDAE Latreille, 1806

Genus: Gasteracantha Sundevall, 1833

Type-species : G. cancriformis (Linnaeus, 1758)

1833. Gasteracantha Sundevall, Conspectum Arachnidum: 14.

1895. Gasteracantha: Simon, Hist. Nat. Araign. 1(4): 845.

1900. Gasteracantha: Pocock, Fauna Brit. India, Arachn.: 231.

1921. Gasteracantha: Gravely, Rec. Indian Mus. 22(4): 416.

1951. Gasteracantha: Sinha, Rec. Indian Mus. 49: 81.

1960. Gasteracantha: Yagiuma, Spiders of Japan in colour: 63.

1960. Gasteracantha: Chrysanthus, Nova Guinea (Zool.), 10(3): 23. 
1982. Gasteracantha: Tikader, Fauna of India, Araneidae, 2(1): 52

1988. Gasteracantha: Davies, Mem. Qld. Mus., 25(2): 31.

1991. Gasteracantha: Chen \& Zhang, Fauna of Zhejiang, Araneida: 101.

1993. Gasteracantha: Zhao, Spiders in the cotton fields of China: 238.

1995. Gasteracantha: Barrion \&Litsinger, Riceland spiders of South \& Southeast Asia: 5

1997. Gasteracantha: Platnick, Advances in Spider Taxonomy: 502.

1997. Gasteracantha: Yin et al., Fauna Sinica, Araneae, Araneidae: 93.

1999. Gasteracantha: Song et al., The Spiders of China: 281.

2004. Gasteracantha: Majumder, Mem. Zool. Surv. India, 20(2): 7.

2006. Gasteracantha: Platnick, World Spider Catalog, version 6.0: 1162.

2007. Gasteracantha: Tanikawa, An identification guide to Japanese spiders: 11.

2009. Gasteracantha: Biswas, In Ahmed (ed.), Encyclopedia of flora \& fauna of

Bangladesh, Arachnida, 18(1): 155.

2012. Gasteracantha: Kim and Lee, Invertebrate fauna of Korea, Araneidae, 21(16): 74.

2014. Gasteracantha: Raychaudhuri and Saha, Atlas of insects and Spiders of BTR: 38.

2018. Gasteracantha: World spider Catalog, Version 19.0, Nat. Hist. Mus. Bern.,

Online at http://wsc.nmbe.ch (accessed on 27th October, 2019).

Diagnosis: Spiders of this genus are medium to large, with shape extremely variable; decorated dorsally with various geometrical shape. Carapace much elevated at the middle and sloping anteriorly and posteriorly. Ocular quad wider behind than in front; median eyes usually subequal. Abdomen large, subquadrate, transverse, oblong or narrowed laterally; integument horny, impressed with large sigilla, with anterior, a posterior spine on either side, the median much longer. Spinnerets much elevated on a large projection occupying a circular space limited by thick flange in the form of a ring.

Biological note: Spiders of this genus are typical orb-weavers. They make specialized geometrical webs in the evening and stay there throughout the day for preying. They are good predators of pest insects.

Distribution: Asia; Australia.

\section{Key to the species}

1. Abdomen laterally narrowed and produced, neither squarish nor rectangular, with 2 transverse bands and many circular markings; sternum medially with scaly reticulation; inner and outer margins of chelicerae with 6 and 5 teeth respectively; epigyne and internal genitalia are as in figs. $1 \mathrm{e} \& 1 \mathrm{f}$ diadesmia

_ Abdomen laterally never narrowed and produced, lateral margins nearly straight, squarish or rectangular; cheliceral margins atmost with 4 teeth; sternum never reticulate; epigyne and internal genitalia never as above

2. Abdomen squarish; cephalothorax without any marking; sternum posteriorly blunt; inner and outer margins of chelicerae with 1 and 2 teeth; epigyne and internal genitalia as in Fig. 2e and Fig. 2f chowdhuryi n. sp.

_ Abdomen rectangular ; cephalothorax with a ' $\mathrm{V}$ '-shaped marking; sternum posteriorly with a spoon like marking, pointed ; each of inner and outer margins of chelicerae with 4 teeth; epigyne and internal genitalia as in Figs. $3 \mathrm{e}$ and $3 \mathrm{f}$.... kuhlii 
1. Gasteracantha diadesmia Thorell (Figs. 1a-f; 4.a)

1887. Gasteracantha diadesmia Thorell, Ann. Mus. civ. Genova,25: 225.

1900. Gasteracantha diadesmia: Pocock, Fauna of Brit. India, Arachn.: 234.

1982. Gasteracantha diadesmia: Tikader, Fauna of India, Araneidae, 2(1): 61.

1995. Gasteracantha diadesmia: Barrion \& Litsinger, Riceland Spiders of South \&Southeast Asia: 557.

1997. Gasteracantha diadesmia: Platnick, Advances in Spider Taxonomy: 502.

1997. Gasteracantha diadesmia: Yin et al., Fauna Sinica, Araneidae: 95.

1999. Gasteracantha diadesmia: Song et al., The Spiders of China: 281.

2006. Gasteracantha diadesmia: Platnick, World Spider Catalog, Version 6.5: 1165.

2009. Gasteracantha diadesmia: Biswas: In Ahmed (ed.), Encyclopedia of flora \& Fauna of Bangladesh,Arachnida, 18(1): 156.

2014. Gasteracantha diadesmia: Raychaudhuri \& Saha, Atlas of Insects \& Spiders of B.T.R.: 38 .

2018. Gasteracantha diadesmia: World Spider Catalog, Version 19.0, Nat. Hist. Mus. Bern

Online at http://wsc.nmbe.ch (accessed on 27th October, 2019).

Material examined: 1 q, Rajshahi, 03.IV.1992, Coll. V. Biswas; 2 qfemale, Rangpur, 05.04.1993, Coll. V. Biswas; 19, Sylhet, 28. XII.1993, Coll. V. Biswas.

General: Cephalothorax light brown, legs brown; abdomen yellow with black transverse bands. Total body length $12.20 \mathrm{~mm}$. Carapace $4.10 \mathrm{~mm}$ long, $5.00 \mathrm{~mm}$ wide ; abdomen $8.10 \mathrm{~mm}$ long and 18.20 mm wide.

Cephalothorax: Wider than long, anteromedially wide, anterior margin straight with a median protuberance; medially with a ' $\mathrm{Y}$ '- shaped marking. Eyes yellowish-white, both rows recurved; anteromedians smallest and situated on a median protuberance; lateral eyes close. Chelicerae brown, broad, robust, each of inner and outer margins with 6 and 5 teeth (Fig. 1b). Maxillae brown, longer than wide, anteromedially wide and scopulate (Fig. 1c). Labium brown, longer than wide, medially bluntly produced, posterior margin straight, anteriorly scopulate (Fig. 1c). Sternum elongate, posteriorly produced and pointed, medially with white scales, clothed with sharp spines (Fig. 1d). Legs brown, strong, comparatively shorter, clothed with spines and hairs; leg formula 1243 and the measurements (in $\mathrm{mm})$ are shown in Table 1.

Table 1. Measurements ( in $\mathrm{mm}$ ) of different leg segments of G. diadesmia Thorell.

\begin{tabular}{ccccccc}
\hline Leg & Femur & Patella & Tibia & Metatarsus & Tarsus & Total \\
\hline I & $1.50 / 1.50$ & $0.50 / 0.50$ & $1.00 / 1.00$ & $1.00 / 1.00$ & $0.60 / 0.60$ & $4.60 / 4.60$ \\
II & $1.20 / 1.20$ & $0.40 / 0.40$ & $1.00 / 1.00$ & $0.90 / 0.90$ & $0.60 / 0.60$ & $4.10 / 4.10$ \\
III & $0.90 / 0.95$ & $0.30 / 0.30$ & $0.70 / 0.70$ & $0.80 / 0.80$ & $0.40 / 0.40$ & $2.10 / 2.15$ \\
IV & $1.00 / 1.00$ & $0.30 / 0.30$ & $0.80 / 0.80$ & $0.80 / 0.80$ & $0.50 / 0.50$ & $3.40 / 3.40$ \\
\hline
\end{tabular}

Abdomen: Broad, much wider than long, antero and posterolateral angles spiny; medially with 2 lateral pointed projections; posterior margin curved with 2 sharply pointed, elongate spines; dorsum decorated with yellow and black transverse bands and some sigillae; margin with sharply pointed spines; ventrally black; epigyne and internal genitalia as in Fig. 1e and 1f.

Distribution: Bangladesh: Rajshahi, Rangpur and Sylhet; Myanmar; India; Thailand (Tikader 1982). 


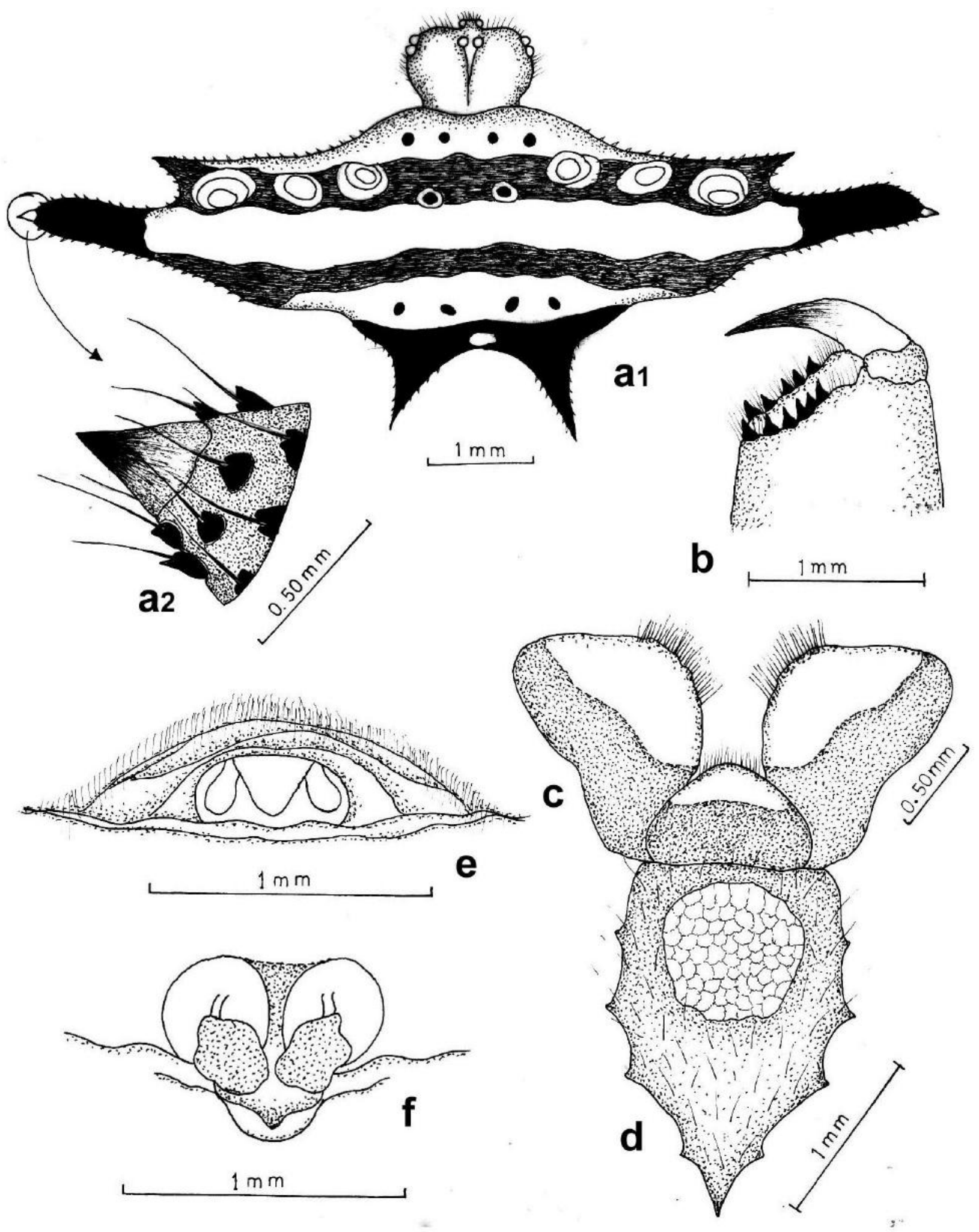

Fig. 1. Gasteracantha diadesmia Thorell: a. Dorsal habitus; b. Chelicerae; c. Maxillae \& Labium; d. Sternum; e. Epigynum; and $\mathbf{f}$. Internal genitalia. 
2. Gasteracantha chowdhuryi n. sp. ( Figs. 2a-f; 4.b-c ).

General: Cephalothorax and head yellow brown; legs brownish with brown small spines. Total body length $10.00 \mathrm{~mm}$. Carapace $3.00 \mathrm{~mm}$ long, $3.10 \mathrm{~mm}$ wide; abdomen $7.00 \mathrm{~mm}$ long and $5.00 \mathrm{~mm}$ wide.

Cephalothorax: Nearly squarish, wider than long, basally wide, anteriorly faintly narrowed, clothed laterally with fine hairs. Eyes pearly white; anterior row strongly recurved and posterior row faintly so; anteromedians situated on a tubercle marginally; lateral eyes close and longer than anteromedians; ocular quad squarish. Chelicerae brown, small, each of inner and outer margins with 1 and 2 teeth respectively (Fig. 2b). Maxillae brownish, longer than wide, anteriorly broad and scopulate (Fig. 2c). Labium yellowish brown, nearly triangular, anteriorly bluntly pointed and scopulate (Fig. 2c). Sternum elongate, posteriorly narrowed and produced, clothed with sharp spines, anterior margin straight (Fig. 2d). Legs slender, comparatively smaller; leg formula 1243 and the measurements (in $\mathrm{mm}$ ) are shown in Table 2.

Table 2. Measurements (in mm) of leg segments of G. chowdhuryi n. sp.

\begin{tabular}{ccccccc}
\hline Leg & Femur & Patella & Tibia & Metatarsus & Tarsus & Total \\
\hline I & $1.50 / 1.50$ & $0.50 / 0.50$ & $1.00 / 1.00$ & $1.00 / 1.00$ & $0.60 / 0.60$ & $4.60 / 4.60$ \\
II & $1.20 / 1.20$ & $0.40 / 0.40$ & $0.90 / 0.90$ & $0.90 / 0.90$ & $0.60 / 0.60$ & $4.00 / 4.00$ \\
III & $0.90 / 0.90$ & $0.20 / 0.20$ & $0.80 / 0.80$ & $0.80 / 0.80$ & $0.50 / 0.50$ & $3.30 / 3.30$ \\
IV & $1.00 / 1.00$ & $0.30 / 0.30$ & $0.80 / 0.80$ & $0.85 / 0.85$ & $0.50 / 0.50$ & $3.45 / 3.45$ \\
\hline
\end{tabular}

Abdomen: Broad, roughly hexagonal, anteriorly broad, posterior margin concave; dorsum decorated with numerous scattered white bands; epigyne and internal genitalia as in Fig. 2e and 2f.

Holotype: 1 i (in spirit), Coll. V. Biswas.

Paratypes: $2 q+$, same as for the holotype.

Type-locality: Bangladesh: Dhaka and Manikganj.

Etymology: The species is named after Professor Amalesh Chowdhury, former Head, Department of Marine Science, University of Calcutta, India, who continuously encouraged during the study.

Economic importance: $G$. chowdhuryi n. sp. can make typical geometrical webs during sun down in the garden and forests. These are good predators and consume small insect pests which are catched by the webs. These are nocturnal in habit and become active during night time.

Remarks: The new species G. chowdhuryi n. sp. does not show any amount of similarity with the other members of Gateracantha species (Tikader 1982, Koh 1989, Yaginuma 1986, Davies 1988, Chen and Zhang 1991, Zhao 1993, Yin et al.1997, Song et al. 1999, Tanikawa 2007, Kim and Lee 2012, Raychaudhuri and Saha 2014) excepting G. mammosa C. L. Koch in having much short anterior median and posterior spines and in dorsal decoration. However, the species stands distinct because of different epigynum, squarish abdomen and in other characters as well. 


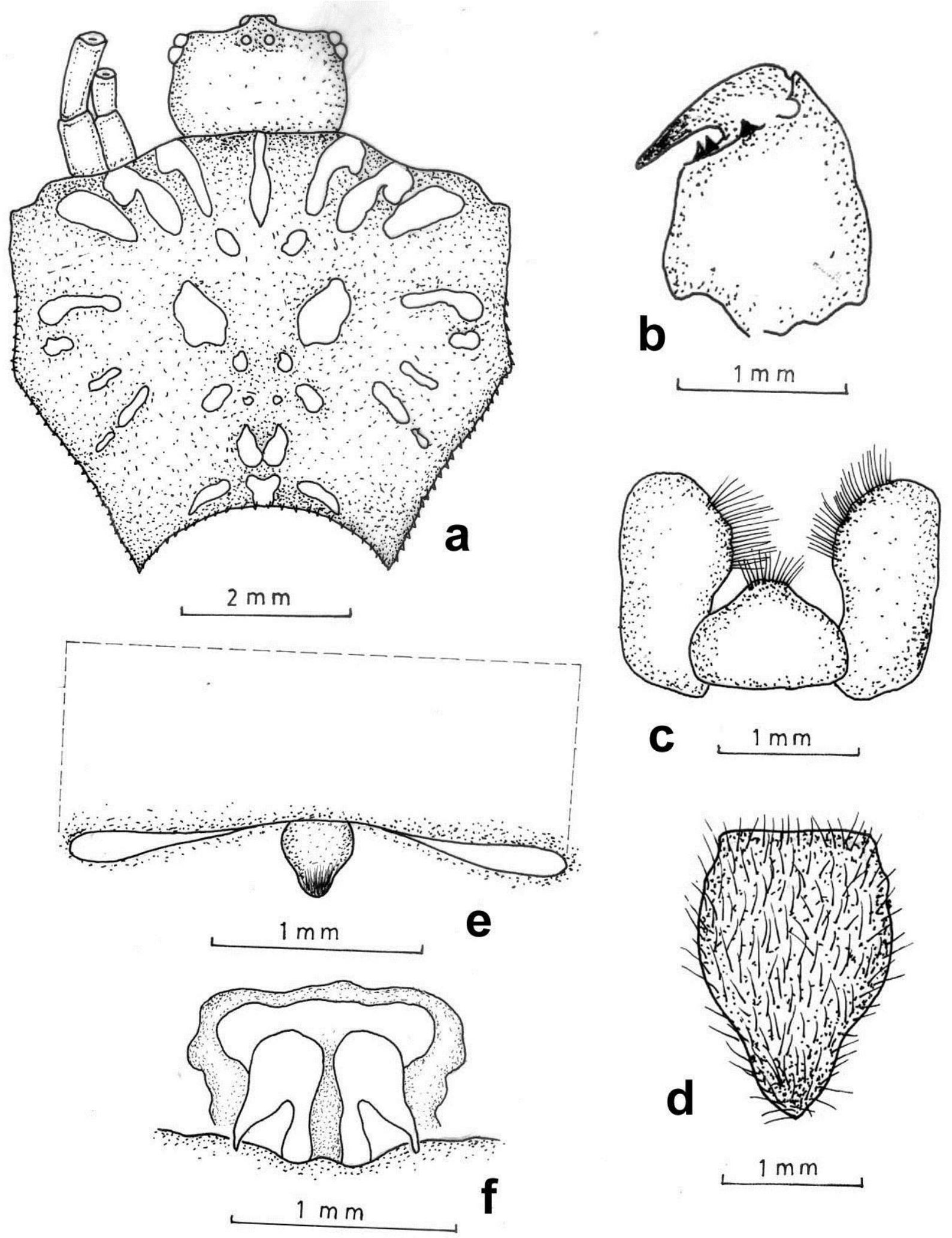

Fig. 2. Gasteracantha chowdhuryi n. sp.: a. Dorsal habitus; b. Chelicerae; c. Maxillae and Labium; d. Sternum; e. Epigynum; and f. Internal genitalia 
3. Gasteracantha kuhlii Koch (Figs. 3a-f; 4-I.d)

1838. Gasteracantha kuhlii C. L. Koch, Die Arachniden, 4: 20.

1841. Plectana acuminata: Walckenaer, Hist. Nat. Ins. Apt., 2: 159.

1845. Gasteracantha annulipes: C. L. Koch, Die Arachniden,11: 52.

1859. Plectana leucomelas: Doleschall, Act. Soc. Ind. Neerl., 5(5): 42.

1886. Gasteracantha annamita: Simon, Act. Soc. Linn. Boradeaux, 40: 148.

1887. Gasteracantha leucomalaena: Thorell, Ann. Mus. civ. Genova,: 231.

1900. Gasteracantha leucomelaena: Pocock, Fauna Brit. India, Arachn.,: 235.

1904. Gasteracantha leucomelas: Simon, Miss. Pavie Indo-Chin., Arachn., 3: 283.

1914. Gasteracantha (Gasteracantha) kuhlii : Dahl, Mitt. Zool. Mus. Berl.,7: 262.

1951. Gasteracantha leucomelaena: Sinha, Rec. Indian Mus., 49: 83.

1970. Gasteracantha leucomelaena: Tikader, Rec. zool. Surv. India, 64(1-4): 40.

1982. Gasteracantha kuhlii: Tikader, Fauna of India, Araneidae: 2(1): 59.

1986. Gasteracantha kuhlii: Yaginuma, Spiders of Japan in colour: 111.

1991. Gasteracantha kuhlii: Chen \& Zhang, Fauna of Zhejiang, Araneida: 101.

1993. Gasteracantha kuhlii: Zhao, Spiders in the cotton fields in China: 238.

1995. Gasteracantha kuhlii: Barrion \&Litsinger, Riceland spiders of South \& Southeast Asia: 559

1997. Gasteracantha kuhlii: Platnick, Advances in Spider taxonomy: 502.

1997. Gasteracantha kuhlii: Yin et al., Fauna Sinica, Araneidae: 97.

2007. Gasteracantha kuhlii: Tanikawa, An Identification guide to Japanesespiders: 11.

2009. Gasteracantha kuhlii: Biswas, Encyclopedia of flora \& fauna ofBangladesh: 158.

2012. Gasteracantha kuhlii: Kim and Lee, Invertebrate fauna of Korea, 21(16): 74.

2014. Gasteracantha kuhlii: Raychaudhuri and Saha, Atlas of insects \& spiders of BTR: 39.

2018. Gasteracantha kuhlii: World Spider Catalog, Version 19.0, Nat. Hist. Mus., Bern.

Online at http://wsc.nmbe.ch (accessed on 27th October, 2019).

Material examined: $1 q$ Jessore, 12 .VIII. 1992, Coll. V. Biswas; $2 q q$, Rangpur, 03. V. 1993, Coll. V. Biswas; 1 , , Sylhet, 02. XII. 1993, Coll V. Biswas; 4우 Bagerhat, 18.II. 1992, Coll. V. Biswas and 22. V. 1993, Coll. V. Biswas.

General: Cephalothorax and abdomen yellow; legs yellowish brown. Total body length $9.80 \mathrm{~mm}$. Carapace $2.50 \mathrm{~mm}$ long, $2.70 \mathrm{~mm}$ wide ; abdomen $7.30 \mathrm{~mm}$ long and $7.00 \mathrm{~mm}$ wide.

Cephalothorax: Wider than long, anterolaterally wide, margin straight, medially with a ' $V$ '-shaped marking. Eyes yellowish-white, both rows recurved; anteromedians smallest and situated on a protuberance; lateral eyes close. Chelicerae brown, broad, strong; each of inner and outer margins with 4 teeth (Fig. 3b). Maxillae brown, broad, slightly longer than wide, anteriorly broad and posteriorly narrowed, scopulate (Fig. 3c). Labium brownish, triangular, anteriorly bluntly pointed, scopulate (Fig. 3c). Sternum elongately triangular, posteriorly pointed (Fig. 3d). Legs slender, comparatively shorter, clothed with spines and hairs; leg formula 1234 and the measurements (in mm) as shown in Table 3.

Table 3. Measurements (in mm) of leg segments of G. kuhlii Koch.

\begin{tabular}{ccccccc}
\hline Leg & Femur & Patella & Tibia & Metatarsus & Tarsus & Total \\
\hline I & $1.50 / 1.50$ & $0.50 / 0.50$ & $1.00 / 1.00$ & $1.00 / 1.00$ & $0.60 / 0.60$ & $4.60 / 4.60$ \\
II & $1.10 / 1.10$ & $0.40 / 0.40$ & $0.85 / 0.85$ & $0.80 / 0.80$ & $0.60 / 0.60$ & $3.75 / 3.75$ \\
III & $1.00 / 1.00$ & $0.30 / 0.30$ & $0.60 / 0.60$ & $0.80 / 0.80$ & $0.50 / 0.50$ & $3.20 / 3.20$ \\
IV & $1.00 / 1.00$ & $0.20 / 0.20$ & $0.70 / 0.70$ & $0.70 / 0.70$ & $0.50 / 0.50$ & $3.10 / 3.10$ \\
\hline
\end{tabular}



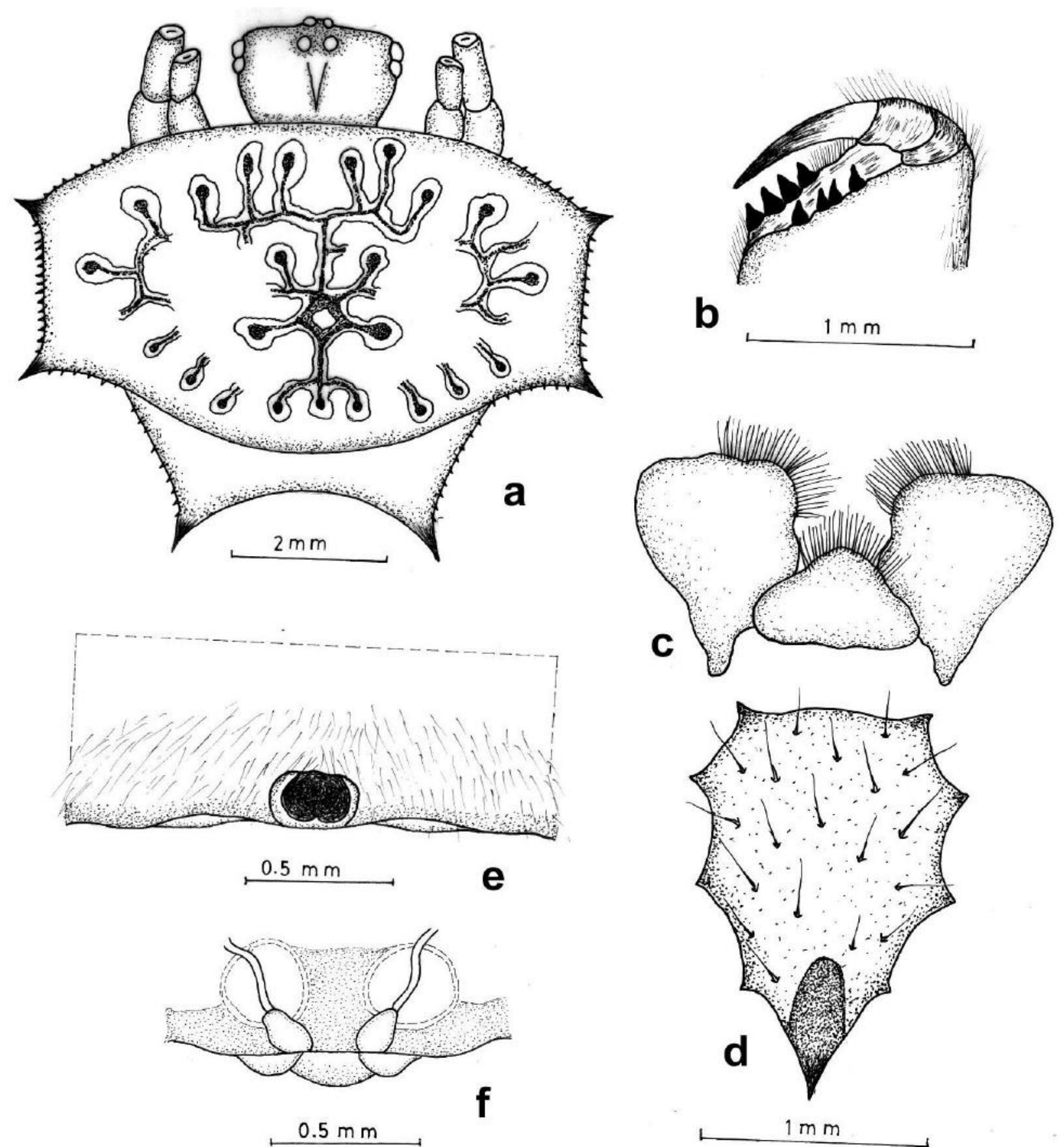

Fig. 3. Gasteracantha kuhlii Koch: a. Dorsal habitus; b. Chelicerae; c. Maxillae \& Labium; d. Sternum; e. Epigynum; and $\mathrm{f}$. Internal genitalia.

Abdomen: Broad, wider than long, rectangular, anterolateral and posterolateral angles spiny, margins with linearly arranged small, thick spines; dorsum beautifully decorated; posterior margin concave, produced with spiny angles; ventrally pale; less decorative; epigyne and internal genitalia (Fig. 3e, 3f)

Distribution: Bangladesh: Bagerhat, Jessore, Rangpur and Sylhet; Bhutan; India; Indo-Malayasia; Japan (Tikader 1982). 

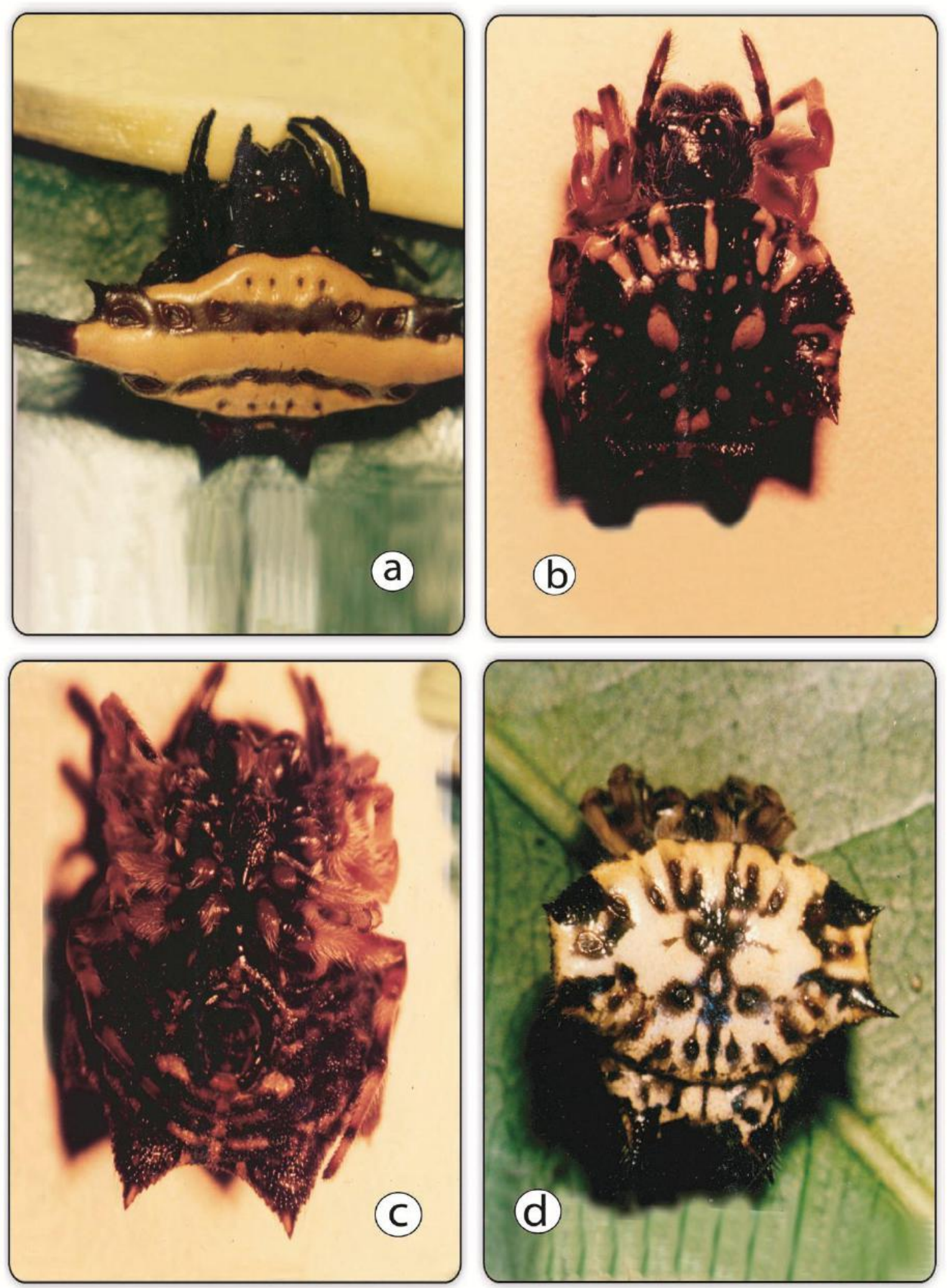

Fig. 4. Pictorial view: a. Gasteracantha diadesmia Thorell (dorsal habitus); b. Gasteracantha chowdhuryi n. sp. (dorsal habitus); c. Gasteracantha chowdhuryi n. sp. (ventral habitus); and d. Gasteracantha kuhlii Koch (dorsal habitus). 


\section{ACKNOWLEDGEMENTS}

The authors are grateful to Dr. S. C. Majumder, Scientist-SD, Zoological Survey of India, Kolkata, for confirming the identity of the species and the Honourable Vice-Chancellor, RKMMVERI for providing laboratory facilities during the study.

\section{REFERENCES}

Barrion, A. T. and J. A. Litsinger. 1995. Riceland spiders of South and Southeast Asia. CABI-IRRI. 700pp.

Begum, A. and V. Biswas. 1997. A list of spider fauna of Barisal division, Bangladesh. Bangladesh J. Zool. 25(2): 207-210.

Biswas, V. 2009. (In Ahmed ed.) Encyclopedia of flora and fauna of Bangladesh: Arachnida. Asiatic Society of Bangladesh, Dhaka. 437 pp.

Biswas, V., H. R. Khan, N. Q. Kamal and A. Begum. 1993. A preliminary study on the rice-field spiders of Jhenidah, Bangladesh. Bangladesh J. Zool. 21(1): 85-92.

Chowdhury, S. H. and S. Nagari. 1981. Rice field spiders from Chittagong. Proc. Zool. Soc. Bangladesh. pp. 53-72.

Chowdhury, S. H and S. K. Pal. 1984. Further report on rice field spiders from Bangladesh. Chittagong Univ. Stud. II. 8(1): 25-39.

Davies, V. T. 1988. An illustrated guide to the genera of orb-weaving spiders in Australia. Mem. Qld. Mus. 25(2): 273-332.

Kaston, B. J. 1972. How to know the spiders. 2nd ed. Wm. C. Brown Co. Pub., Dubuque, Iowa. 289 pp.

Keswani, S., P. Hadole and A. Rajoria. 2012. Checklist of spiders (Arachnida: Araneae) from India. Indian J. Arachnol. 1(1): 1-129.

Kim, S. T. and S. Y. Lee. 2012. Invertebrate fauna of Korea (Arthropoda: Arachnida: Araneae: Araneidae), Araneid spiders. Nat. Inst. Biol. Res. 21(16): 146.

Koh, J. K. H. 1989. A guide to Singapore spiders. Singapore Science Centre. 160 pp.

Kolosvary, G. 1931. Variation - Studien uber 'Gasteracantha' und 'Argyope'Arten. Archivio Zoologico Italiano, 16: 1055-1085.

Levi, H. W. 1965. Techniques for the study of spider genitalia. Psyche. 72(2): 152-158.

Lincoln, R. J. and J. G. Sheals. 1985. Invertebrate Animals, collection and preservation. British Museum (Natural History), London, UK. 150 pp.

Okuma, C., N. Q. Kamal, Y. Hirashima, Z. Alam and T. Ogata. 1993. Illustrated monograph of the ricefield spiders of Bangladesh. IPSA - JICA, Salna, Gazipur, Bangladesh. 93 pp.

Raychaudhuri, D. and S. Saha. 2014. Atlas of insects and spiders of Buxa Tiger Reserve. West Bengal Bio-Diversity Board and Nature Books India, Kolkata, India. 357 pp.

Song, D. X., M. S. Zhu and J. Chen. 1999. The Spiders of China. Hebei Sci. \& Tech. Pub. House, Chiana. 640 pp.

Tanikawa, A. 2007. An identification guide to Japanese spiders of the families Araneidae, Nephilidae and Tetragnathidae. Arachnological Society of Japan. 121 pp. 
Tikader, B. K. 1982. Fauna of India, Araneidae (=Argiopidae), Vol. II, Part-1. Zoological Survey of India, Kolkata, India. 293 pp.

Tikader, B. K. 1987. Handbook of Indian Spiders. Zoological Survey of India, Kolkata, India. 251 pp.

World Spider Catalog. 2019. World Spider Catalog, Version 19.0, Nat. Hist. Mus., Bern., Online at http://wsc.nmbe.ch (accessed on 27th October, 2019).

Yaginuma, T. 1986. Spiders of Japan in colour. 2nd ed. Hoikusha Pub. Co. Ltd., Osaka, Japan. 305 pp.

Yin, C. M., J. Wang, M. S. Zhu, L. P. Xie, X. J. Peng and Y. Bao. 1997. Fauna Sinica, Arachnida (Araneae: Araneidae). Science Press, Beijing, China. 460 pp. 